\title{
Peningkatkan Keterampilan Menulis Huruf Kapital Melalui Media Game Edukasi Kahoot pada Bahasa Indonesia Kelas 2 di SDN Kedungrejo 02 Kecamatan Pilangkenceng
}

\section{Purno Widodo}

Universitas Sebelas Maret

purwopb@gmail.com

\author{
Article History \\ received 30/4/2021
}

\begin{abstract}
The purpose of this study was to describe the results of improving writing skills using the Kahoot game media in grade 2 students of SDN Kedungrejo 02, Pilangkenceng District. This research is a classroom action research that was conducted for two cycles. Cycles I and II have two meetings each. Each meeting consists of four stages, namely planning, implementation, observation, and reflection. The research subjects were all students of SDN Kedungrejo 02 Kecamatan Pilangkenceng Madiun Regency for the 2020/2021 academic year, totaling 7 students. Data collection techniques in this study, namely: observation, interviews, and tests. Data validity uses source triangulation and technique triangulation. The results of the test data showed that there was an increase from pre-cycle to cycle II. The success of the research in accordance with the indicators of success can be in the second cycle, ie $86 \%$ of learners completed KKM, the average value rat a student in each cycle experienced a rise. In the precycle, the average score of students is 48.6 or below the KKM. In the first cycle, the average value of the students was 57.1. In cycle II the average score of students increased to 74.3 or above the KKM. Based on the analysis and discussion of the research results, it can be concluded that the Kahoot educational game media succeeded in improving capital letter writing skills in online learning in grade 2 students of SDN Kedungrejo 02, Pilangkenceng District, Madiun Regency for the 2020/2021 academic year.
\end{abstract}

Keywords: Writing Skills Letter Capital, Educational Games Kahoot, Indonesian

\begin{abstract}
Abstrak
Tujuan penelitian ini adalah mendiskripsikan hasil peningkatan keterampilan menulis menggunakan media game kahoot pada peserta didik Kelas 2 SDN Kedungrejo 02 Kecamatan Pilangkenceng. Penelitian ini adalah penelitian tindakan kelas yang dilakukan selama dua siklus. Siklus I dan II masing-masing dua pertemuan. Pada tiap pertemuan terdiri atas empat tahapan yaitu perencanaan, pelaksanaan, observasi, dan refleksi.Subjek penelitian adalah seluruh siswa II SDN Kedungrejo 02 Kecamatan Pilangkenceng Kabupaten Madiun tahun pelajaran 2020/2021 yang berjumlah 7 siswa. Teknik pengumpulan data pada penelitian ini, yaitu: observasi, wawancara, dan tes. Validitas data menggunakan triangulasi sumber dan triangulasi teknik. Analisis data melalui reduksi data, penyajian data, dan penarikan kesimpulan. Keberhasilan penelitian sesuai dengan indikator keberhasilan di dapat pada siklus II, yaitu $86 \%$ peserta didik tuntas KKM, nilai rata-rata peserta didik di setiap siklus mengalami kenaikan. Pada prasiklus nilai rata-rata peserta didik adalah 48,6 atau di bawah KKM. Pada siklus I nilai rata-rata peserta didik adalah 57,1 . Pada siklus II nilai rata-rata peserta didik meningkat menjadi 74,3 atau di atas KKM. Berdasarkan analisis dan pembahasan hasil penelitian dapat disimpulkan bahwa media game edukasi kahoot berhasil meningkatkan keterampilan menulis huruf kapital dalam pembelajaran daring pada siswa kelas 2 SDN Kedungrejo 02 Kecamatan Pilangkenceng Kabupaten Madiun tahun pelajaran 2020/2021.
\end{abstract}

Kata kunci: Keterampilan Menulis Huruf Kapital, Game Edukasi Kahoot, Bahasa Indonesia. 


\section{PENDAHULUAN}

Menurut Suhendra (2015:5) Keterampilan menulis adalah keterampilan seseorang untuk menuangkan ide dalam sebuah tulisan. Hal ini selalu dianggap sulit karena orang-orang menganggap ide lebih mudah dituangkan dalam bentuk bahasa lisan. Menurut KBBI, huruf kapital atau huruf besar adalah huruf yang berukuran dan berbentuk khusus (lebih besar daripada huruf biasa), biasanya digunakan sebagai huruf pertama dari kata pertama dalam kalimat, huruf pertama nama diri dan sebagainya, seperti A, B, C, D, E. Penggunaan huruf kapital harus sesuai dengan pedoman umum ejaan bahasa Indonesia yang disempurnakan. Dalam buku Pedoman Umum Ejaan Bahasa Indonesia yang Disempurnakan dijelaskan bahwa terdapat 15 aturan penggunaan serta tata cara penulisan huruf kapital.Adapun 15 aturan penggunaan huruf kapital, yaitu sebagai berikut :Sebagai huruf pertama pada kata pertama dalam suatu kalimat; Sebagai huruf pertama dalam kalimat petikan langsung; Sebagai huruf pertama untuk ungkapan/sebutan yang berhubungan dengan Tuhan, kitab suci serta kata ganti untuk menyebut Tuhan; Sebagai huruf pertama untuk menyebutkan nama gelar kehormatan, keturunan dan keagamaan (hanya jika diikuti oleh nama seseorang yang dimaksudkan); Sebagai huruf pertama sebutan/gelar, jabatan dan pangkat seseorang (hanya jika diikuti oleh nama orang yang dimaksudkan atau jika nama orang tersebut diganti dengan nama instansi maupun nama tempat ia berkedudukan); Sebagai huruf pertama nama orang; Sebagai singkatan nama orang; Sebagai huruf pertama nama bahasa, suku, bangsa dan agama; Sebagai huruf pertama nama tempat, lokasi secara geografis;Sebagai huruf pertama nama negara, lembaga pemerintahan, ketatanegaraan serta nama dokumen resmi; Sebagai huruf pertama perulangan kata suatu badan/instansi, lembaga pemerintah, ketatanegaraan dan dokumen resmi; Sebagai huruf pertama nama buku, majalah, surat kabar, judul karangan; Sebagai huruf pertama singkatan gelar, pangkat maupun sapaan; Sebagai huruf pertama kata penunjuk kekerabatan (baik yang diikuti dengan atau tanpa nama orang yang dimaksudkan).

Bahasa Indonesia adalah alat komunikasi yang dipergunakan oleh masyarakat Indonesia untuk keperluan sehari-hari,misalnya belajar,bekerja sama,dan berinteraksi. Bahasa Indonesia merupakan bahasa nasional dan bahasa resmi di Indonesia. Bahasa nasional adalah bahasa yang menjadi standar di Negara Indonesia. Sebagai bahasa nasional,bahasa Indonesia tidak mengikat pemakainya untuk sesuai dengan kaidah dasar. Bahasa Indonesia digunakan secara non resmi,santai dan bebas. Pembelajaran Bahasa Indonesia SD diarahkan untuk meningkatkan kemampuan peserta didik dalam berkomunikasi dengan baik, baik secara lisan maupun tulisan. Di samping itu, dengan pembelajaran bahasa Indonseia juga diharapkan dapat menumbuhkan apresiasi peserta didik terhadap hasil karya sastra Indonesia. Standar kompetensi pembelajaran Bahasa Indonesia di SD merupakan kualifikasi minimal peserta didik, yang menggambarkan penguasaan keterampilan berbahasa, dan sikap positif terhadap bahasa dan sastra Indonesia.

Kahoot adalah permainan berbasis platform pembelajaran gratis, sebagai teknologi pendidikan.Kahoot adalah sebuah website di internet yang dapat menghadirkan suasana kuis yang meriah dan hebohkedalam kelas.Dengan bermain Kahoot ini pembelajaran menjadi sangat menyenangkan dan membuat para peserta didik tidak bosan mengikuti pembelajaran yang sangat sulit dimengerti.Nsmun bermian Kahoot ini sangat memerlukan koneksi internet itulah syarat utamanya.Karena kuis atau pertanyaan yang tersedia dan dibuat menggunakan kahoot hanya bisa dimainkan secara online.

Berdasarkan uraian diatas tujuan penelitian mendiskripsikan hasil peningkatan keterampilan menulis menggunakan media game kahoot pada peserta didik Kelas 2 SDN Kedungrejo 02 Kecamatan Pilangkenceng. 


\section{METODE}

Jenis penelitian yang digunakan adalah penelitian tindakan kelas.Dalam penelitian ini, peneliti berkolaborasi atau bekerjasama dengan guru kelas. Peneliti bekerjasama dengan guru kelas 2 di SDN Kedungrejo 02 Kecamatan Pilangkenceng dalam persiapan, pelaksanaan, refleksi, dan perencanaan untuk siklus selanjutnya. Subjek penelitian ini adalah peserta didik kelas 2 di SDN Kedungrejo 02 Kecamatan Pilangkenceng Kabupaten Madiun pada semester II (genap) tahun ajaran 2020/2021. Adapun jumlah peserta didik sebanyak 7 peserta didik, terdiri dari 3 peserta didik laki-laki dan 4 peserta didik perempuan. Penelitian tindakan kelas ini terdiri dari empat langkah yaitu perencanaan, tindakan, observasi dan refleksi.

Pengumpulan data menggunakan tiga teknik yaitu teknik tes, observasi, dan angket. Tes sebagai instrumen sangat baik digunakan dalam penelitian tindakan kelas. Tes ini digunakan untuk mengetahui tingkat kemampuan pembelajaran setelah proses pembelajaran secara daring pada peserta didik kelas II SDN Kedungrejo 02 Kecamatan Pilangkenceng Kabupaten Madiun. Observasi digunakan untuk mengetahui apakah pembelajaran sesuai dengan skenario atau tidak dan mengidentifikasi hambatan-hambatan dalam pembelajaran.Lembar observasi yang digunakan yaitu lembar kesiapan peserta didik dalam menerima pelajaran dan lembar observasi peserta didik dan guru selama pembelajaran berlangsung. Angket digunakan untuk mengajukan beberapa pernyataan tertulis pada google form/microsoft office dikirimmelalui WAG untuk memperoleh data tentang penggunaan kahoot dalam kegiatan belajar peserta didik.

Data observasi dianalisa secara kuantitatif dan kualitatif dan disajikan secara deskriptif naratif.Skor data observasi. Untuk menganalisis hasil tes digunakan analisis kuantitatif, yaitu dengan penskoran nilai, kemudian mencari rata-rata nilai dan ketercapaian KKM.

\section{HASIL DAN PEMBAHASAN}

Penelitian tindakan kelas di SDN Kedungrejo 02 Kecamatan Pilangkenceng Kabupaten Madiun pada tahun pelajaran 2020/2021 dilaksanakan dalam dua siklus. Setiap siklus dilakukan dalam satu kali pertemuan.Materi pelajaran yang digunakan dalam penelitian ini adalah pelajaran Bahasa Indonesia mengambil materi penulisan huruf kapital. Pada siklus I guru menerapkan media pembelajaran berupa video dalam proses pembelajaran dengan platform zoom. Kegiatan pembelajaran dimulai dari guru menjelaskan langkah-langkah pembelajaran. Kemudian guru menjelaskan singkat materi. Ada peserta didik yang tidak mendengarkan penjelasan guru. Ketika diberi kesempatan bertanya, peserta didik juga tidak berani bertanya. Kinerja guru pada siklus I masih belum maksimal. Guru masih ada kendala pada jaringan serta penyampaina guru masih ada yang belum jelas. Sehingga penelitian dilanjutkan pada siklus II. Sama seperti siklus I, di siklus II guru menjelaskan materi secara singkat. Peserta didik terlihat lebih fokus mendengarkan penjelasn guru. Guru bertanya jawab dengan peserta didik terkait materi. Peserta didik mulai percaya diri ketika pembelajaran berlangsung.

Hasil observasi pada kinerja guru di peneltian tindakan kelas ini mulai menunjukkan peningkatan disetiap siklusnya. Pada siklus I, kinerja guru masuk dalam kategori cukup. Hal ini terjadi karena guru masih belum mampu mengoperasikan platform yang digunakan sehingga terjadi kendala dalam pemutaran video pembelajaran. Di siklus II, kinerja guru masuk dalam kategori baik. Hal ini terjadi karena guru telah belajar dari hasil refleksi pada siklus sebelumnya. Di siklus II guru mampu menerapkan pembelajaran dengan baik. Hasil observasi peserta didik yang dilakukan observer memperlihatkan bahwa siklus I aktivitas peserta didik dalam kategori cukup. Pada siklus II masih ada peserta didik yang tidak mendengarkan penjelasan guru dan sedikit yang menjawab atau bertanya. Peserta didik kurang 
menunjukkan minat belajar yang baik. Pada siklus II aktivitas peserta didik masuk dalam kategori baik. Hal itu ditandai dengan peserta didik yang tampak percaya diri ketika mengkuti pembelajaran.

Pada sikkus II telah mennunjukkan perkembangan yang sangat baik dari segi aktivitas peserta didik maupun kinerja guru. Sama pada siklus I dan II, guru menjelaskan materi secara singkat. Peserta didik terlihat fokus mendengarkan penjelasan guru. Guru bertanya jawab dengan peserta didik terkait materi. Peserta didik juga terlihat lebih percaya diri dan antusias dalam pembelajaran. Selain itu penggunan media game edukasi kahoot memudahkan siswa dalam mengerjakan soal evaluasi ataupun latihan yang diberikan oleh guru. Peserta didik menjadi lebih tertarik dan bersemangat mengerjakan tugas-tugas yang diberikan.Tujuan penilitian ini adalah meningkatkan keterampilan menulis huruf kapital peserta didik melalui game edukasi kahoot terlihat dari tabel berikut ini :

Tabel 1. Kemampuan ketrampilan menulis huruf kapital peserta didik

\begin{tabular}{lccc}
\hline & Pra siklus & Siklus I & Siklus II \\
\hline Jumlah Peserta Didik Tuntas KKM & 1 & 3 & 6 \\
\hline \% Peserta Didik tuntas KKM & $14 \%$ & $43 \%$ & $86 \%$ \\
\hline Rata-Rata Nilai Peserta Didik & 48,6 & 57,1 & 74,3 \\
\hline
\end{tabular}

Untuk melihat peningkatan ketrampilan menulis huruf kapital dapat dilihat pada grafik berikut ini

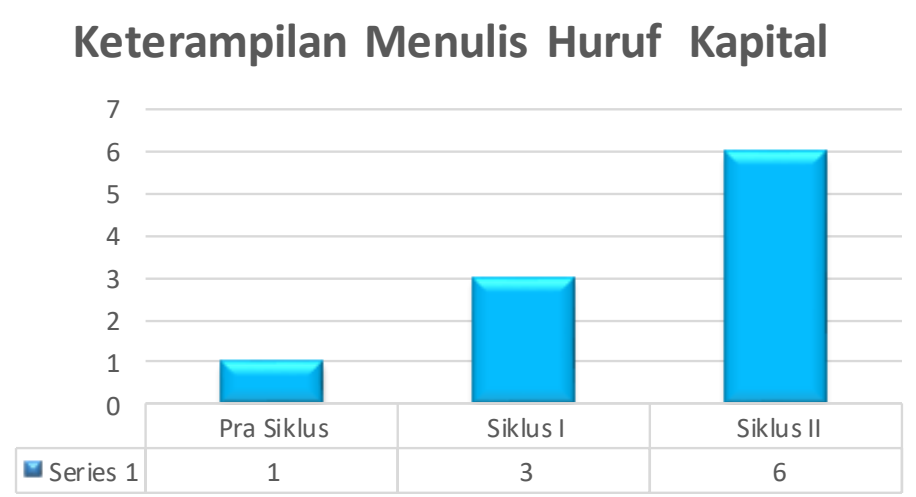

Gambar 1 Grafik Peningkatan Ketrampilan Menulis Huruf Kapital

Pada gambar 1 terlihat di tahap pra siklus hanya 1 dari 7 peserta didik tuntas KKM. Kemudian pada siklus I meningkat menjadi 2 dari 7 peserta didik. Kemudian pada siklus II meningkat menjadi 6 dari 7 peserta didik.

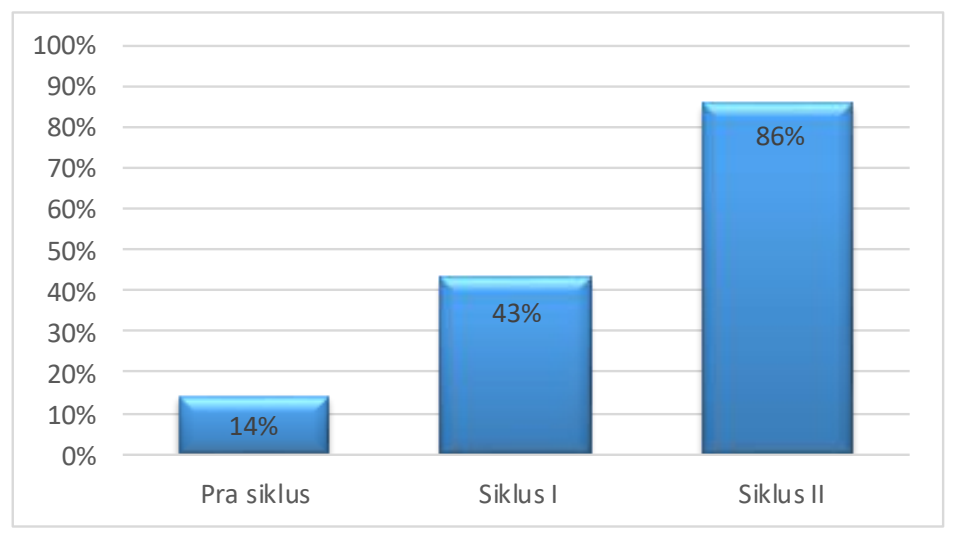

Gambar 2 Grafik Peningkatan Presentase Peserta didik 
Pada gambar 2 ditahap prasiklus hanya 14\% peserta didik tuntas KKM Kemudian pada siklus I meningkat menjadi $43 \%$. Lalu pada siklus II kembali meningkat menjadi $86 \%$ peserta didik tuntas KKM.

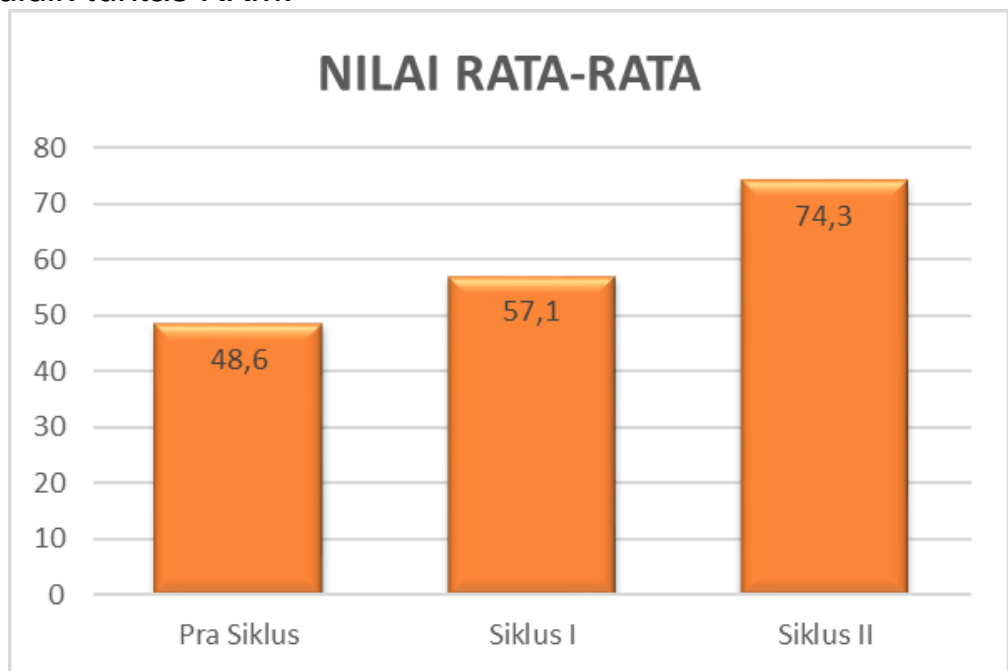

Gambar 3 Grafik Nilai Rata-rata Peserta didik

Pada gambar 3 Rata-rata nilai peserta didik pada tahap prasiklus hanya 48,6. Kemudian pada siklus I meningkat menjadi 57,1. Lalu pada siklus II kembali meningkat menjadi 74,3 . Indikator keberhasilan dari penelitian ini adalah $70 \%$ pesta didik tuntas KKM. Pada siklus I hanya 43\% peserta didik tuntas KKM hal ini terjadi karena :

a. Jaringan tidak stabil

b. Peserta didik baru mengenal platform yang digunaka

c. Peserta didik tidak menyimak dengan baik penjelasan guru

d. Kemampuan guru dalam mengelola kelas virtual penggunaan zoom belum terampil.

Pada siklus II, guru membuat modifikasi pembelajaran menggunakan zoom dan media yang lebih menarik agar peserta didik lebih berminat terhadap materi yang diajarkan. Langkah perbaikan guru di siklus II adalah :

a. Pemberian bahan ajar yang sesuai dengan karakteristik peserta didik

b. Menggaktifkan peserta didik dengan bertanya jawab

Hasil dari perbaikan siklus II 86\% peserta didik tuntas KKM. Dengan nilai ratarata peserta didik adalah 74,3 , sehingga pada siklus II ini sudah dinyatakan bahwa penerapan media game edukasi kahoot dapat meningkatan keterampilan menulis huruf kapital.

Dengan demikian media game edukasi kahoot berhasil meningkatkan keterampilan menulis huruf kapital dalam pembelajaran daring pada siswa kelas II SDN Kedungrejo 02 Kecamatan Pilangkenceng Kabupaten Madiun tahun pelajaran 2020/2021.

\section{SIMPULAN}

Berdasarkan hasil penelitian mengenai Indikator keberhasilan peningkatan pembelajaran peserta didik pada penelitian ini dilihat dari $70 \%$ peserta didik tuntas KKM (dengan nilai 70). Hasil penelitian dapat dilihat dari data tes dan angket minat belajar. Hasil penelitian dari data tes memperlihatkan bahwa pasa prasiklus terdapat $14 \%$ (1 peserta didik) tuntas KKM. Pada siklus I terdapat $43 \%$ (3 peserta didik) tuntas KKM sehingga siklus dilanjutkan. Kemudian pada siklus II terdapat $86 \%$ (6 peserta didik) tuntas KKM sehingga siklus dihentikan. Data tersebut memperlihatkan terjadi peningkatan dari prasiklus sampai siklus II. Keberhasilan penelitian sesuai dengan 
indikator keberhasilan di dapat pada siklus II, yaitu $86 \%$ peserta didik tuntas KKM, nilai rata-rata peserta didik di setiap siklus mengalami kenaikan. Pada prasiklus nilai ratarata peserta didik adalah 48,6 atau di bawah KKM. Pada siklus I nilai rata-rata peserta didik adalah 57,1. Pada siklus II nilai rata-rata peserta didik meningkat menjadi 74,3 atau di atas KKM.

Berdasarkan pada penelitian tindakan kelas yang peneliti lakukan, maka peneliti memberikan saran-saran sebagai berikut : (1)Penyusunan bahan ajar yang menarik agar peserta didik mau membaca materi yang diberikan, (2)Perlu diadakan penelitian lebih lanjut tentang pembelajaran dengan media pembelajaran ini, tidak hanya pada mata pelajaran bahasa indonesia akan tetapi bisa dapat diaplikasikan kedalam pembelajar tematik, (3) Selalu berinovasi dalam setiap kegiatan pembelajaranya agar peserta didik tidak jenuh dan bosan, (4)Jangan terlalu banyak memberikan tugas-tugas yang monoton kepada peserta didik.

\section{DAFTAR PUSTAKA}

Arikunto Suharsimi. 2011. Dasar-dasar evaluasi Pendidikan. Jakarta :Bumi aksara Arikunto Suharsimi. 2009. Penelitian Tindakan Kelas. Jakarta: Bumi Aksara

Arikunto Suharsimi. 2001. Prosedur Penelitian. Jakarta: Rineka Cipta

Gulo .W. 2003. Strategi Belajar Mengajar. Jakarta; PT. Grasindo

Herry Hernawan Asep. 2009. Pembelajaran Tematik (Konsep Dasar Pembelajaran Tematik). Jakarta: Kementerian AgamaDerektorat Jendral Pendidikan Islam

Kementrian Pendidikan dan Kebudayaan RI. 2011. Peraturan Mendiknas tentang

Satuan Pengawasan Internal (Permendiknas Nomor 47 tahun 2011). Jakarta: Penulis.

Roestiyah N.K. Strategi belajar mengajar. Jakarta: Rineka Cipta

Sanjaya Wina. 2006. Strategi Pembelajaran. Jakarta: Kencana Prenadamedia Group 